\title{
KLÁŠŤOV HILL - AN EXCEPTIONAL CASE OF RELIGIOUS CUSTOMS AND NOTIONS IN THE SLAVIC WORLD (EASTERN MORAVIA, CZECH REPUBLIC)
}

\author{
P A V E L K O U Ř I L
}

\begin{abstract}
The paper offers relevant information concerning Kláštov, the dominant summit of the Vizovice Hills in eastern Moravia, where Moravia's highest-positioned stronghold was built in the period of the Lusatian Urnfield culture. Later, in the $9^{\text {th }}$ and $10^{\text {th }} \mathrm{c}$., it was used by the domestic population above all for cult purposes; traces of a more permanent occupation have not been detected there yet. Text also presents an exceptional local find of a brass inlaid trefoil iron sword set fitting, probably a local imitation of Carolingian models (?). It represents a high-quality, professionally made art and craft product whose popularity culminated in the second and third quarters of the $9^{\text {th }} \mathrm{c}$. in the West; it might have occurred also later in the Moravian milieu.
\end{abstract}

Keywords: Moravia, Early Middle Ages, Great Moravian Period, cult site, sword fitting.

The Staré Město - Uherské Hradiště agglomeration, part of the fertile lower Morava River valley, is wedged between the Chriby Mountains in the west and the Vizovice Hills and White Carpathians in the east. The beginnings of a Slavic occupation there might date as far back as the first half of the $6^{\text {th }} \mathrm{c}$. (Galuška 2017, 20), presented by sporadic settlements with Prague type pottery such as Kvačice, Ostrožská Nová Ves, Polešovice, Staré Město or Zlechov. In the course of the $7^{\text {th }}, 8^{\text {th }}$ and especially $9^{\text {th }} c$., the settlement network densified to such an extent that some researchers even speak about overpopulation; almost 70 settlements have been detected in a radius of ca. $10 \mathrm{~km}$ from Uherské Hradiště (Hrubý $1982,131)$. The occupation was gradually shifting to the east and south-east, including the area of the Vizovice Hills. It is their highest summit, Kláštov

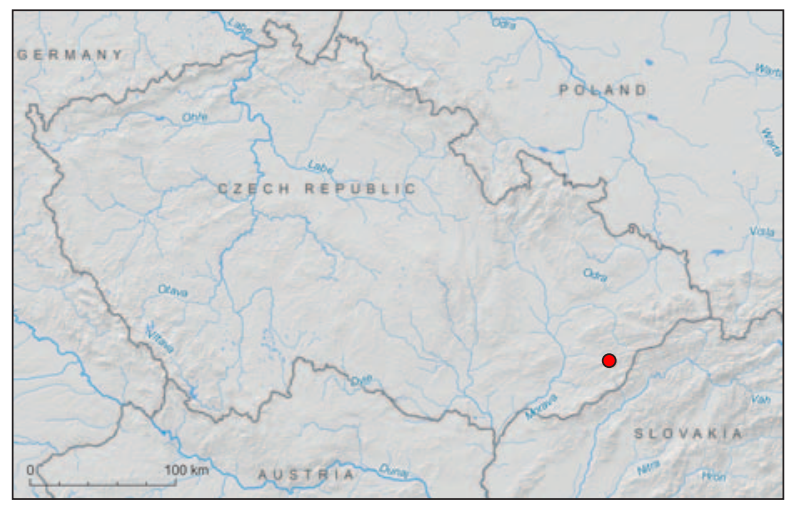

Fig. 1. Kláštov. The site marked on the Czech Republic map (graphics M. Vlach).
(753 m a.s.l.), part of the so-called Kláštov Ridge, that is the subject of our interest (Fig. 1). The trend is documented above all by numerous cremation (Lipová, Nevšová, Slavičín, perhaps also Haluzice or Uherský Brod), biritual (Bojkovice, Hluk, Rudimov) and especially inhumation barrow cemeteries, often with rich grave goods testifying to a clear social stratification of the burying community (Částkov, Horní Němčí, Nedachlebice(?), Přečkovice(?), Rudimov: Kohoutek 1995a, 131-146; Kouřil/Tymonová 2013, 154, 155); with the exception of these barrow cemeteries, however, other evidence of Middle or Late Hillfort period occupation is not very distinctive.

The Vizovice Hills themselves, comprising the north-western part of the Moravian-Slovakian Carpathians, are rather rugged, built predominantly of flysch rocks. We can encounter outcrops of lower-quality iron ore including clay ironstone or clay siderite and limonite; they have been mined virtually continuously up to the Modern Era (e.g. Bojkovice, Březolupy, Mařatice, Rudice, Rudimov with remnants of excavation works, or Chrastěšov where features of a production character, apparently related to iron ore processing, are considered). We can, therefore, realistically presume that this was so also at the time of the emergence and especially of the subsequent rapid expansion of the Mojmirid domain culminating in the second half or the last third of the $9^{\text {th }} c$. and that this area participated considerably in supplying (not only) the main Great Moravian centres with this important strategic raw material. The excellency of Great Moravian craft, based on earlier home production and conditioned 
among other things by purposeful exploitation of the raw material base, a good communications system and the possibilities of the production and sales in agglomerations of an 'urban' type, was reflected above all in smithery, girdlery and jewellery. It is assumed that Moravian smiths, already focused on specialised activities, were capable of forging about one hundred iron products including highly functional tools. This figure seems to be fully confirmed and, in many cases, even increased precisely by the finds from Kláštov (Vysoké Pole cadastral territory, Zlín distr.).

The highest-located stronghold in Moravia was built on its summit sloping southwards at the time of the Lusatian Urnfield culture (HB-C), with a triangular layout and an area of ca. 2 hectares, delimited by a rampart with a wood-and-stone internal structure that is still 3 metres high today (Červinka 1928, 91; Čižmár̆ M. 2004, 265, 266, with further literature; Kohoutek 2006a). Although a sporadic presence of pottery fragments and, exceptionally, also parts of querns of the Hillfort period have been detected in the not very extensive earlier and later excavation works (Kohoutek 2006a), it was not and, in fact, is not yet quite clear whether the Slavs really occupied the area on a more permanent basis and whether they might have made use of an earlier fortification system. A recent limited area excavation has not detected any demonstrable feature from this period, as a cultural layer is evidently missing and the evidence available has the form of not very numerous and predominantly very small pottery fragments (Frolíková-Kaliszová 2015; Kohoutek 2007a; Kohoutek/ Pavličková 2008), which might possibly indicate intentional fragmentation(?).

Nevertheless, the situation changed diametrically with the rapid and massive onset of metal detectors in the early third millennium, as the site became a subject of systematic illegal looting using this technology. Only these activities, bringing information - considerably delayed - to the professional community of an incredible quantity and variety of early medieval artefacts found at the site, moved the authorised institutions to commence their own programme of the rescue of the remaining metallic items. This task was assumed by the Institute for Archaeological Heritage Brno (ÚAPP). Under the guidance of J. Kohoutek, 8 hoards were excavated; 2 were gained from the metal detector users (Geisler/Kohoutek 2014); besides that, hundreds of solitarily deposited individual finds were gath- ered and documented. The activity was continued by other employees of the ÚAPP and of the Zlín Museum (Čižmár I. 2010; Čižmář I./Kohoutek 2015, 187-190; Langová 2010). Based on an agreement between the UAPP, the Institute of Archaeology, Czech Academy of Sciences, Brno (ARÚB) and the municipal authority of Vysoké Pole, on whose cadastral territories the stronghold is situated, the archaeological field activities on Kláštov Hill and its immediate vicinity was taken over by the Academy's Brno-based institute as of 2011. Its engagement (lasting until 2016), based on systematic research of purposefully chosen districts including ones outside the stronghold's area, brought about the excavation of two more hoards (no. 12 and 13) and more than 400 separately deposited artefacts; ${ }^{1}$ one more hoard (no. 11) was provided for detailed processing by an amateur detector (Profantová 2014). Although we do not know yet the precise number of the items found (whole and in fragments) held by the named institutions including the municipality of Vysoké Pole, our realistic estimate based on already published and personally communicated information is around 2,$100 ;{ }^{2}$ the contents of hoards comprise less than one-seventh of this number(!). According to information that is difficult to verify, about one-third, possibly up to one-half, of this number is also in the private hands. This is an absolutely unique and unexpected quantity for a single site. Moreover, we should keep in mind that the complex has not been completely surveyed and 'extracted' yet. Regrettably, as illegal activities continue unabatedly, the leak of information is enormous. The exceptional character of Kláštov stands out if we consider that a work from the second half of the 1980s discussing Slavic iron hoards from the territory of former Czechoslovakia lists over 1,700 items from 37 (predominantly Moravian) sites, more than a half of them consisting of axe-shaped bars and partially also of slag (Bartošková 1986). This remains true even after taking into account numerous hoards newly gained in the Czech lands and the latest list of early medieval iron hoards from Slovakia that includes 74 of them. Only two sites from this Slovak list, of a somewhat different character than Kláštov, namely the Bojná hillfort (where systematic research has been conducted for many years by dear jubilant K. Pieta) and Pobedim (with its close vicinity), have an increased number of iron hoards, but their composition is mostly considerably different, with axe-shaped bars predominant (Müllerová 2020).

\footnotetext{
1 The survey was carried out by a group led by Ondrej Šedo. The artefacts gathered, about 500 of them, are undergoing the preservation process; after it is completed, they will be documented and professionally assessed.

2 The number is several times higher than the number of pottery fragments gathered so far (Frolíková-Kaliszová 2015, 202).
} 


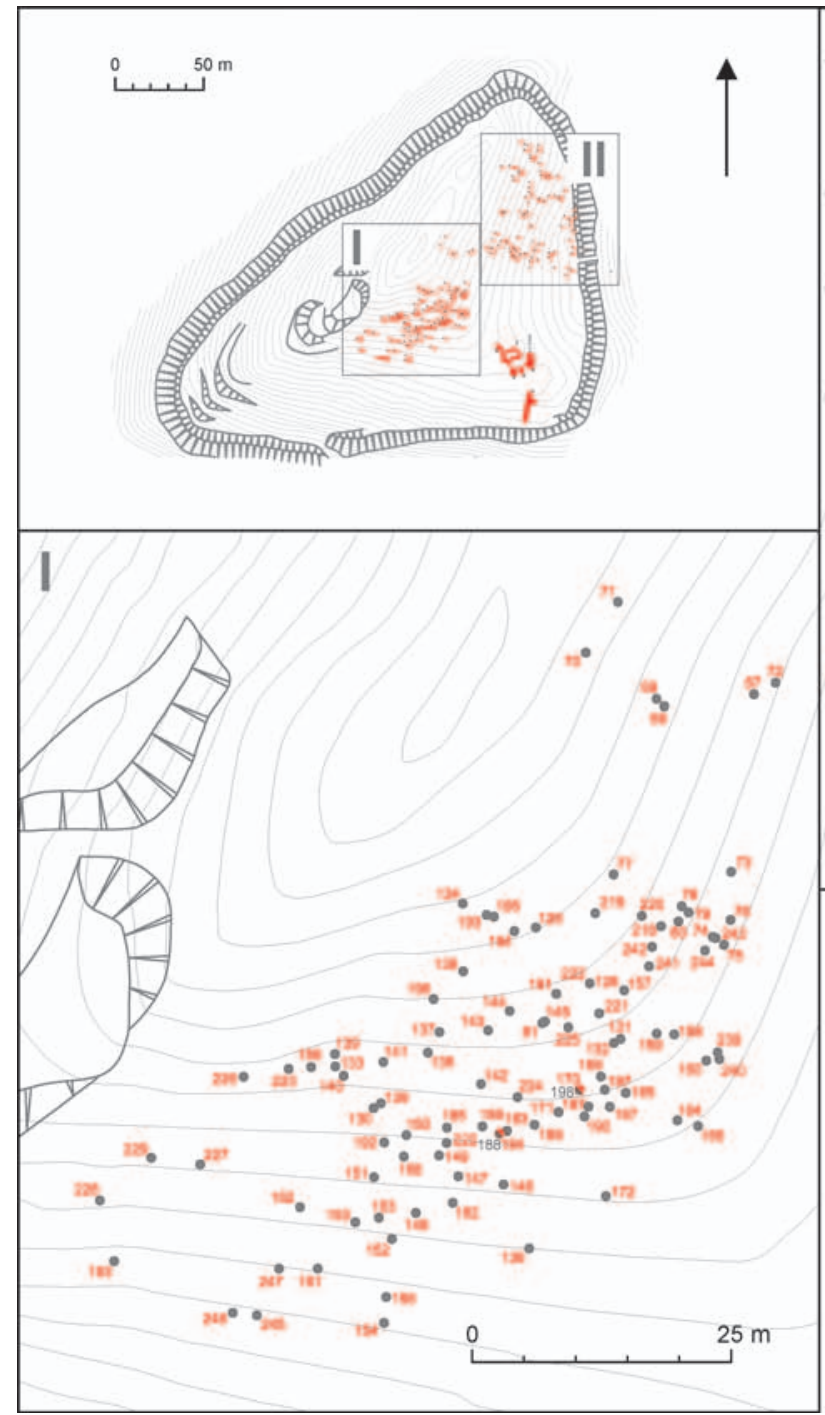

The outlined situation leads to numerous questions; the answers, of course, depend on the publication of relevant data on the discoveries made so far and of at least an enumerative list of the artefacts gained, especially those that were not part of hoards and that, in our opinion, cannot be regarded as lost or temporarily deposited items. The basic questions are probably the following: Where - what and in what manner - by whom and why - when and how long was deposited? The answer to the first, relatively least complicated question, where the deposition took place, is seemingly simple: it was the highest point of the whole mountain range, the Kláštov Hill itself; but was it really only there? We know today that hoards and solitary finds alike can be found not only within the fortified complex but also on its slopes, near access roads and saddles as well

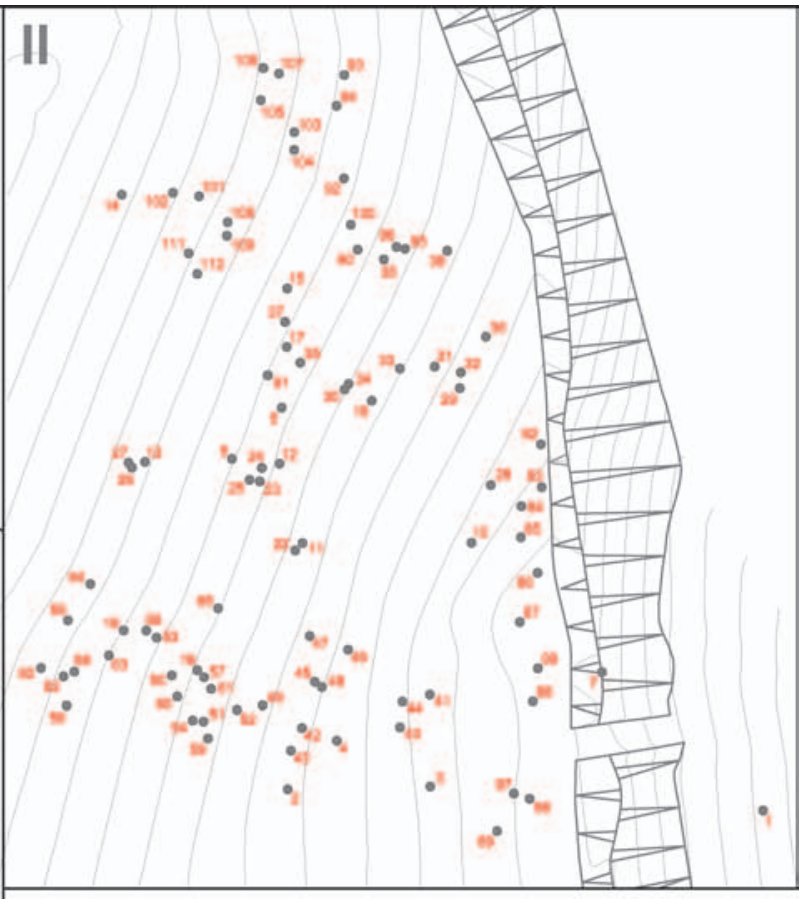

Fig. 2. Kláštov. Contour-line plan of the stronghold with the positions of the individual finds marked (graphics by J. Fritsch).

as close to springs, sometimes at a considerable distance from the dominant hill. After all, water always played an important role with the Slavs (and other Indo-Europeans) in connection with the notions of a permanently reviving cosmos and the regeneration of nature (here, we can point out also traces of completely disintegrated iron items in the so-called cistern sunken within the fortified area). Only selected districts of the fortified area were used for this purpose (two considerable cumulations have been recorded), far from the whole area protected by the rampart (Fig. 2).

What and in what manner was deposited? Iron items were deposited above all, including miniaturised specimens; non-ferrous metal artefacts comprise a tiny percentage. They usually lay in rather shallow positions below the surface. ${ }^{3}$ For the

\footnotetext{
3 Some partly reached the surface and were well visible. It is characteristic of the site that even later, for the whole subsequent centuries, these artefacts were apparently not sought and collected by the local population as material for further use. Their position and purpose were respected; the tradition of the place must have been intensively perceived.
} 
time being, however, we do not know whether their locations were part of some system and order and whether the activity was organised and controlled by someone who was permanently present there or whether they were deposited haphazardly - the latter seems to be more likely. As we have stated, two areas were evidently preferred: the neighbourhood of the highest isolated rock block (Čertův kámen [Devil's Rock]; geologically, it is a so-called tor) and an artificially adapted terrace with a water source. As for the hoards, it is also not clear whether the individual items were put one onto another according to their belonging to the individual functional categories or in some other order given in advance, or without any order. It is rather evident that they were mostly deposited quite loosely or only slightly bound; others might have been placed in a textile wrapping (the remnants of textiles have indeed been detected on some fragments) or a leather sack. Package material in the form of a metal kettle, a ceramic vessel or a bucket has not been recorded; in one case, a hoard was overlaid by a quern stone (Kohoutek 2006b). Products related to agriculture and crafts (especially woodworking) predominate quite clearly, followed by items related to horse and rider equipment, lockable systems, etc. As we have stated, weapons are minimally represented, except for axes and partially also arrowheads. Jewellery is missing altogether, so are belt fittings, with a single exception, etc. The metal artefacts gathered so far can be divided into three groups in terms of the state of preservation: undisturbed functional products that may be a) either brand new, or b) used (we are unable to distinguish between these two categories without special observations, if it ever will be possible; the non-numerous items that bear traces of repairs belong here as well), and defective artefacts, which are present in the hoards as well as outside them. It is not yet quite clear whether these items were devalued by long use or damaged intentionally, although the former possibility seems more realistic.

Who deposited them and why? We will hopefully not be very far from the truth if we link hoards, especially more extensive ones, to smiths (forge tongs and blades, massive wedges, punches) and possibly also to the direct producers of iron; here, we have in mind especially semi-finished products - bun-shaped iron blooms, lead ingots but also slag (Čižmár I. 2010). We should not lose sight of other categories of the population either, however, especially more affluent ones. In view of the great variety and high quality of the items con- tained in the individual hoards and outside them, we are inclined, at the present stage of knowledge of the site, to the opinion that they were at least partly produced by specialists at sites of a central type; in this case, they worked in the radius of the Staré Město - Uherské Hradiště agglomeration, ca. 50-70 km distant from Kláštov. In contrast to that, solitarily deposited mostly simpler products might have (not necessarily) been linked to the activity of more ordinary, less affluent people from the nearer and further vicinity; we must admit we do not know how large the territorial radius of these 'contributors' was.

We are reaching the key issue - the reason that led the Slavic population to use precisely the area of the highest summit of the Vizovice Hills and its nearest hinterland so massively for the intentional storage of iron products, highly valuable and valued at that time. We believe that their deliberate deposition to or under the ground was not motivated by fear of a war danger at a time of unrest, as presumed for most hoards from sites with long-term and dense occupation (cf. Bartošková 1986, 109), whose depositors believed that they would be collected again later, after the danger had passed (bearing in mind, of course, that any unambiguous interpretation of the reason for deposition is rather tricky). On the contrary, we are of the opinion that these are hoards and individual items of a votive character, deposited as offerings, as was suggested earlier, with a question mark, by J. Kohoutek and P. Pavličková (2008). Among other things, the area fulfils the socalled triad of conditions for Slavic sacrificial sites a spring, a sacred grove (tree) and a central stone, here represented by the dominant so-called Devil's Stone with an artificially adapted platform covered with a cinereous layer (Kajkowski/Kuczkowski 2009; Kohoutek 2007b, 32; Profantová/Profant 2004, 160; to Perun in detail and comprehensively: Téra 2017). It, therefore, seems acceptable to presume under the current state of knowledge that Perun might have been, with a certain probability, venerated above all there as the supreme god of the Slavonic pantheon, the lord of thunder, lightning and storms, linked in Slavonic folklore to the person of a mythical smith and to smithery in general (e.g. Gieysztor 2006, 65). ${ }^{4}$ As his profiling attribute was an axe (Váňa 1990, $71,72)$, the relatively higher number of axes found at the site so far, although mostly inaccessible at present, situated in a private collection, may also testify to the veneration of this deity. As we have mentioned, sacrifices were made also to springs, lakes, stones, trees, celestial bodies of day or night,

\footnotetext{
4 It should be mentioned that we know even from the present that this hill attracts the most lightning strikes and related thunder during summer storms.
} 
mountains, hills, etc. It is, of course, possible that Kláštov fulfilled more functions (e.g. refugial, cf. Kajkowski 2019, esp. 107-121), but its function as a sacral place (for this issue, see e.g. Szczepanik 2020, 258-261) seems to be primary at this moment (similarly Profantová 2014, 338).

When and how long did the deposition take place? As we have emphasised above, with the exception of items held by the ARÚB and the published hoards, we have only approximate information about the other, prevailing finds, above all from the published data and partially also from autopsy. Based on this knowledge, we are inclined to a tentative and conditioned conclusion that the prevailing majority of the finds can be acceptably linked above all to the advanced Great Moravian horizon, rather than the previous developmental phase or even the $8^{\text {th }} \mathrm{c}$. (stated in their latest work also by Geisler/Kohoutek $2014,106)$. This opinion is corroborated by the unusually varied and qualitatively and quantitatively convincing assortment of finds signalling the production of specialised, advanced crafts. The presence of artefacts such as massive, up to $50 \mathrm{~cm}$ long, coulters found in the company of both symmetrical and asymmetrical ploughshares, short scythes for grass mowing, the type of ring-like, so-called shepherd shears, axe-shaped bars of various weight categories, turning keys related to metal closing systems, spurs exclusively with discs (so far never in a pair and without the related sets), advanced bridle-bits with segmented cheek-pieces (on the contrary, S-shaped cheek-pieces are absent altogether), fittings with a neck, stirrups that can be categorised to the entire $9^{\text {th }}$ c., hackles, etc. do not contradict this notion; after all, pottery material is also treated in the same way (Frolíková-Kaliszová 2015, 209). Some items that might theoretically indicate an earlier start of the area, such as bowls of the Silesian type, have a wide range of occurrence (from the $7^{\text {th }}$ to the $11^{\text {th }} \mathrm{c}$., with a core in the $8^{\text {th }}$ and $9^{\text {th }} \mathrm{c}$.); on the other hand, we find rather robust rhombic arrowheads or spurs with a long prick that could easily be dated to the final phases of the existence of Mojmirid Moravia. Therefore, we judge that Kláštov was used (worshipped) above all during the $9^{\text {th }} \mathrm{c}$., most of all probably at the time of the expansion and bloom of Great Moravia and possibly also after its fall, and that the deposition of the hoards or individual items was gradual. If this premise is correct, it also tells much about the level of Christianisation of the Moravian society, about its apparently shallow conversion and lack of anchoring in the new faith, with areas more distant from the main centres not considerably (or not at all) affected by the evangeli- sation process (Kouřil 2014). The very deposition of the items most probably took place predominantly in the spring and summer months, as it would be difficult in the snow-covered and hard to access terrain in the autumn and especially in the winter; likewise, we can only speculate about the days or part of the day such an act was carried out.

Allow us to end this passage with two observations. First, according to interesting local tradition, as recently as the early $20^{\text {th }} \mathrm{c}$., if modern medical procedures failed, women - mothers (but also fathers) used to go to Kláštov's springs and hang out parts of children's clothing, especially baby shirts, on tree branches there; similar practises are also mentioned, for example, in the milieu of the southern Slavs - in Serbia (Téra 2017, 216). Second, according to some researchers, the nearby castle of Engelsberg (Angels' Mountain), also known as Sehradice in Czech (Kohoutek 1995b, 27-44; Plaček 2001, 205, 206), founded around the middle of the $13^{\text {th }} \mathrm{c}$. by Helembert de Turri, a liege of Bishop of Olomouc Bruno of Schauenburg who colonised the Slavičín region (Bárta 2020, 206-210), was supposed to be an antipole to pagan Kláštov; hence its name. ${ }^{5}$

We consider the text above, a brief introduction of a sort to the issues concerning Kláštov and a possible springboard for further research and professional discourse, necessary to present the most magnificent known artefact gained from the site so far. It is a trefoil fitting, a three-way strap divider belonging to a sword-belt set used to divide the main belt from the auxiliary one (Fig. 3). Without hesitation, it can be described as an art and craft product of unusual quality. It was excavated from the area of the spring basin (examined area X, 2016) in the saddle used to access the hill's summit (Bratřejov cadastral territory). Paradoxically, it was found in an earlier pit made by detector users, who missed this item situated at the very bottom of the pit. We can only theorise on what other finds might have accompanied it; possibly, other parts of a sword-belt set. Let us point out in this context that two parts of a sword itself are available from hoard no. 9, a crossguard and probably also a base of a pommel.

The very well-preserved fitting made of iron sheet, with one leaf visibly longer than the other two, has a maximum size of $9 \mathrm{~cm}$. Two approximately isosceles triangles are plastically rendered in a low relief in its centre. Six transverse brass inlays, flat on the basis and rounded on the top, were inserted in previously cut grooves in each leaf with a maximum width of $3.0-3.1 \mathrm{~cm}$; the rounded part was finished by filing into the form of minute hemispheres in an imitation of beaded wire. The

\footnotetext{
5 For Kláštov and the nearby region from the perspective of folklore archaeology, see most recently M. Hlavica (2009; 2011).
} 


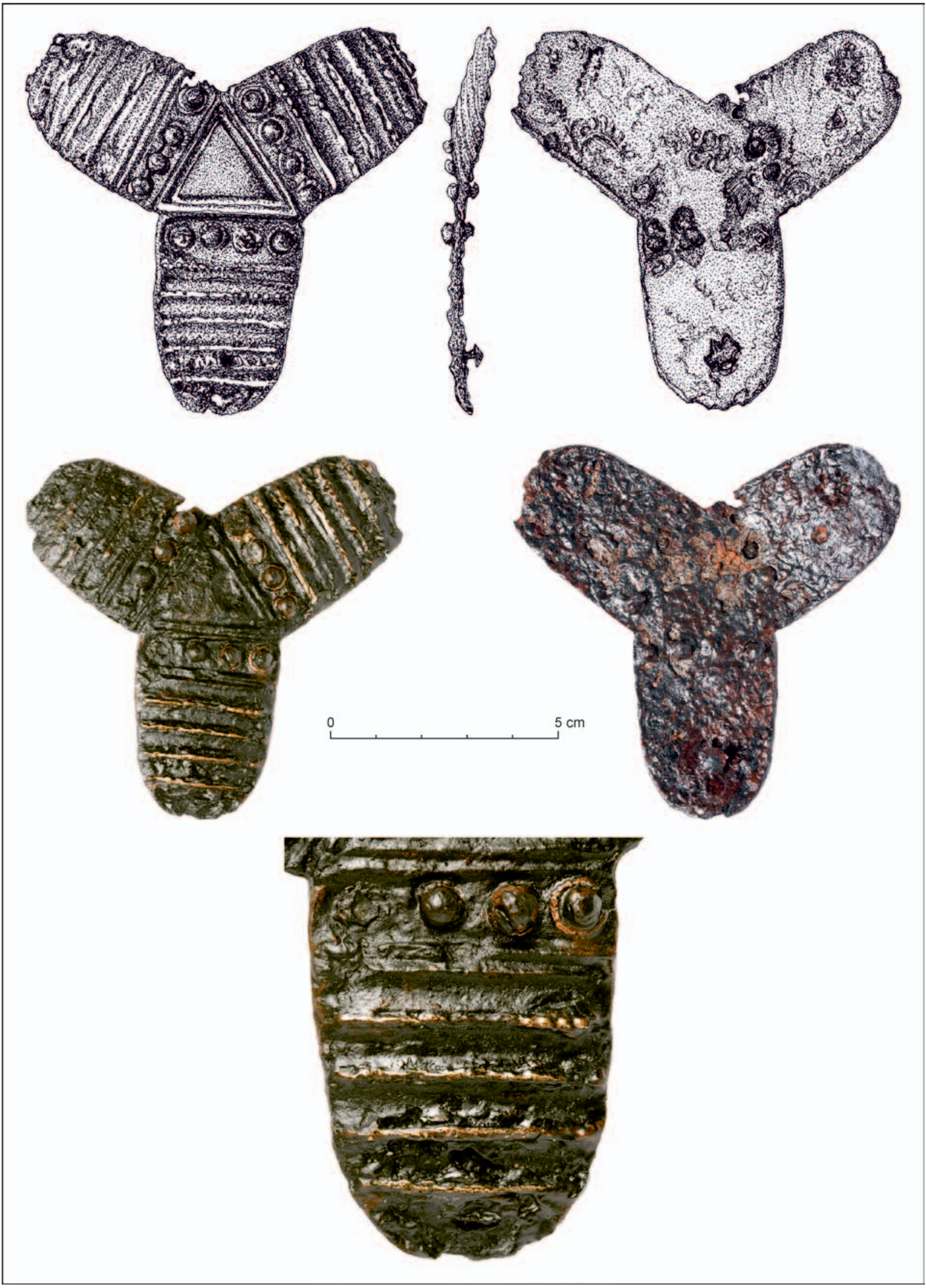

Fig. 3. Kláštov. Trefoil sword set fitting (drawing by J. Grieblerová, photo by J. Foltýn). 
inlays were fastened by so-called caulking along the grooves, as is still well visible in some places. This means that rather than hammering the inlay itself, which is the usual procedure, its immediate vicinity was hammered (otherwise, the hammer strokes would have destroyed the surface finish of the brass inlays). This is not a common procedure; it is much more demanding than a usual inlay, testifying to skilful and advanced craftsmanship. The divider was attached to the belt with 16 iron rivets wrapped in copper wire; another rivet was situated near the rounded part of the longer leaf; ${ }^{6}$ it seems that the 4 rivets with half-round heads on each of the sides of the triangle were equipped with a now hardly discernible, very thick brass washer. An XRF analysis has proved that besides predominant copper (ca. $75 \%$ ), the alloy of the transverse brass inlays contained $15-20 \%$ of zinc; the wires around the rivets were made of unalloyed copper.

As of 2013/2014, 25 three-way (complete or fragmentary) artefacts have been discovered from the European continent as solitary finds, while 12 of these fittings were part of sword-belt sets. The territory of former Czechoslovakia yielded 7 dividers of this form as an integral part of more or less complete sword-belt sets (Kolín, Stará Kouřim, Jarohněvice, 2× Mikulčice, Prušánky, Turčianská Blatnica) and three separate finds (Uherské Hradiště, Bojná, Dolný Kubín-Velký Bysterec); this is quite a decent representation (Robak 2013; with the description of the individual finds and the relevant literature). The Kláštov find has now been added to them.

Sword-belt sets including the above-mentioned trefoil fittings, clearly associated with the Carolingian cultural sphere (despite their rather sparse occurrence there), have been paid increased attention on the domestic professional scene (leaving aside foreign authors), especially in the past decade. The works have systematically concentrated above all on issues concerning their typology (with an emphasis on the structural design of the individual parts and the whole sets and the method of their attachment), ornamentation and its rendition, development, provenance, chronology, function, iconography, symbolism, material analyses, etc. Based on these observations and conclusions, we can categorise the trefoil artefact from Kláštov, belonging to the most widespread group of sword-belt set dividers, very probably to Variant A, less likely to Variant B of the categorisation of this group according to Š. Ungerman $(2011,578-584 ; 2017,256-265)$ or to set type I-Ia or possibly II of the classification by Z. Robak (2013, 140-146; 2018a, 155, 156). These products are characterised by predominant advanced vegetal decoration, occurring in the Western milieu and Scandinavia mostly during the second third of the $9^{\text {th }} \mathrm{c}$. (with the beginnings in the late $8^{\text {th }}$ or early $9^{\text {th }}$ c., e.g. Lennartsson 1997-1998; Wamers 2008, 48, 49); especially in the so-called late Carolingian horizon (c. 840/850-910), it can be encountered also in the milieu of the Moravian Slavs (Robak 2018b, 332-334). Most trefoil dividers, evidently highly popular and fashionable in the Carolingian milieu, can be dated to this time range as well, occurring there roughly from the second quarter of the $9^{\text {th }} \mathrm{c}$. and culminating in the 840s-870s (Robak 2018a, 155; Wamers/Brandt 2005, 54, 55).

Unlike most known specimens with predominant vegetal ornamentation, our fitting is decorated with transverse lines in a demanding inlaid rendition. This is not a decorative technique used very often in the period in question, even though it has been registered, albeit sporadically, in other examples of this type of divider, also in context with a geometric motif. ${ }^{7}$ Let us mention finds from Hildesheim or Balhorn or, from the 'domestic' milieu, the fittings from Dolný Kubín and Staré Město, ${ }^{8}$ which are considered Carolingian imports and dated sometime before the middle of the $9^{\text {th }} \mathrm{c}$. Of course, we must also take into account a unique inlaid piece from Bojná which is, however, decorated with an acanthus stalk (Pieta/Ruttkay 2007, 32; Robak 2013, 105-113, 162, 163, with numerous other examples of inlaid decoration of metallic artefacts including sword parts). For instance, none of the known identically formed bronze (exceptionally even silver) brooches of the Viking period (imitating the Carolingian three-way strap dividers), used mainly in Scandinavia, was decorated in such a way (Maixner 2005).

The more robust parameters of the Kláštov artefact indicate that it is more likely a later product, even though the decoration and the method of its application might date it somewhere to the first half of the $9^{\text {th }}$ c. (Robak 2013, 162). The rendition in iron and the inlay from a base metal signal that

\footnotetext{
6 The longer leaf, which was fixed by another rivet, might have been situated on the auxiliary, more strained belt directed towards the fastening of the lower part of the scabbard. The divide between the underside of the fitting and the hammered head implies that the belt (made of leather or another organic material) was 2-2.5 mm thick. Certain asymmetry of three-way fittings has been ascertained also for some other specimens (e.g. Mikulčice: Robak 2013, 108, 109; Balhorn: Eggenstein 2008 , 129 and others).

7 Geometric decoration was not very popular in the Carolingian sphere, and we cannot find many items decorated in such a manner in the Great Moravian milieu either (cf. e.g. Klanica et al. 2019).

8 With this find, however, it is not certain at all that the inlay technique was used (Galuška 1997, 79).
} 
it was not one of the most prestigious top products of its kind, yet it represents a high-quality, professionally made item. It was undoubtedly used as part of a sword-belt set by a man in a respected elite position, although certainly not the highest on the social ladder. It is difficult to decide whether the fitting should be considered a Western import or a domestic product; some less exclusive iron dividers of this form are ascribed local origin with a certain level of probability (e.g. Jarohněvice, Prušánky, Mikulčice: Košta/Lutovský 2014, 67; on the imitation of Carolingian imports: cf. Profantová 2011). It seems that the fitting was not deposited in the ground as an unused, newly made artefact. This is suggested by the embedded rivets and, above all, by the markedly hammered end part of the rivet on the longer arm, evidently testifying to the attachment to a belt. Theoretically, the complete set including the belts might have been buried; regrettably, we are unable to find this out today. Therefore, it remains unclear who brought the fitting to Kláštov. Was it a warrior, the user of the sword (or might it have been part of his war booty?), or a craftsman, possibly its maker? We do not know, although the latter possibility seems to be somewhat more acceptable. It was not by no means an ordinary item, but it could have been made by Moravian master craftsmen who worked in specialised workshops of the central sites, especially Mikulčice and the nearby Staré Město - Uherské Hradišš̌ (cf. Kouřil 2020, 265-267). Like the predominant mass of the finds from the Kláštov Hill, it was most probably deposited in the advanced Great Moravian horizon.

\section{BIBLIOGRAPHY}

Bárta 2020 - S. Bárta: Tři Brunovi muži aneb pozůstatky disertace, která nikdy nevznikla. In: B. Chocholáč/ J. Malíř/L. Reitinger/M. Wihoda (eds.): Pro pana profesora Libora Jana k životnímu jubileu. Brno 2020, 205-218.

Bartošková 1986 - A. Bartošková: Slovanské depoty železných předmětů v Československu. Studie Archeologického ústavu ČSAV v Brně 13. Praha 1986.

Červinka 1928 - I. L. Červinka: Slované na Moravě a říše Velkomoravská. Brno 1928.

Čižmář I. 2010 - I. Čižmář: Vysoké Pole (okr. Zlín). Přehled výzkumů 51, 2010, 484.

Čižmář I./Kohoutek 2015 - I. Čižmář/J. Kohoutek: Hradisko Kláštov u Vysokého Pole (okr. Zlín). In: K. Pieta/ Z. Robak (eds.): Bojná 2. Nové výsledky výskumov včasnostredovekých hradisk. Archaeologica Slovaca Monographiae. Fontes 20. Nitra 2015, 183-193.

Čižmář M. 2004 - M. Čižmář: Encyklopedie hradišt’ na Moravě a ve Slezsku. Praha 2004.

Eggenstein 2008 - G. Eggenstein: Balhorn in der Merowingerund Karolingerzeit - Fränkische Mode, Schwertträger, Reiterkrieger. In: G. Eggenstein/N. Börste/H. Zöller/ E. Zahn-Biemüller (Hrsg.): Eine Welt in Bewegung. Unterwegs zu Zentren des frühen Mittelalters. München - Berlin 2008, 126-144.

Frolíková-Kaliszová 2014 - D. Frolíková-Kaliszová: K významu Kláštova v době Velké Moravy - místo kultu nebo útočiště? Pravěk. Nová řada 23, 2014, 195-215.

Galuška 1997 - L. Galuška: K problematice předvelkomoravského opevnění Starého Města. In: P. Michna/R. Nekuda/J. Unger (eds.): Z pravěku do středověku. Sborník k70. narozeninám Vladimíra Nekudy. Brno 1997, 73-83.

Galuška 2017 - L. Galuška: Slované - stopy předků. O Moravě v 6.-10. století. Brno 2017.

Geisler/Kohoutek 2014 - M. Geisler/J. Kohoutek: Vysoké Pole-Kláštov. Inventár hromadných nálezủ železných předmětů a shrnutí terénních výzkumných sezon 2005-2007. Pravěk. Supplementum 28. Brno 2014.

Gieysztor 2006 - A. Giesztor: Mitologia Słowian. Communicare - historia i kultura. Warszawa 2006.
Hlavica 2009 - M. Hlavica: Raně středověké kultovní aktivity na vrchu Kláštov a jejich odraz v archeologických pramenech a ústní lidové slovesnosti. Bakalářská diplomová práce. Masarykova univerzita. Filozofická fakulta. Ústav archeologie a muzeologie. Brno 2009. Online available at: https://is.muni.cz/th/edk8j/

Hlavica 2011 - M. Hlavica: Folklórní archeologie a její prameny na Zlínsku. Bakalářská diplomová práce. Masarykova univerzita. Filozofická fakulta. Ústav evropské etnologie. Brno 2011. Online available at: https://is.muni.cz/ th/ni6nk/Text.pdf

Kajkowski 2019 - K. Kajkowski: Obrzędowość religijna Pomorzan we wczesnym średniowieczu. Studium archeologiczne. Wrocław 2019.

Kajkowski/Kuczkowski 2009 -K. Kajkowski/A. Kuczkowski: Słowiańskie święte gaje na Pomorzu we wczesnym średniowieczu. Nasze Pomorze 11, 2009, 25-38.

Klanica et al. 2019 -Z. Klanica/B. Kavánová/P. Kouřil/Š. Ungerman: Mikulčice. Die Nekropole an der dreischiffigen Basilika. Studien zum Burgwall von Mikulčice 12. Spisy Archeologického ústavu AV ČR Brno 58. Brno 2019.

Kohoutek 1995a-J. Kohoutek: Slovanské a středověké osídlení. In: V. Nekuda (red.): Vlastivěda moravská. Zlínsko. Brno - Zlín 1995.

Kohoutek 1995b - J. Kohoutek: Hrady jihovýchodní Moravy. Zlín 1995.

Kohoutek 2006a-J. Kohoutek: Vysoké Pole (okr. Zlín). Přehled výzkumů 47, 2006, 288, 289.

Kohoutek 2006b - J. Kohoutek: Vysoké Pole (okr. Zlín), Kláštov - zjištovací výzkum hradiska, Výroční zpráva ÚAPP Brno 2005. Brno 2006, 32.

Kohoutek 2007a-J. Kohoutek: Vysoké Pole (okr. Zlín). Přehled výzkumů 48, 2007, 520, 521.

Kohoutek 2007b - J. Kohoutek: Vysoké Pole (okr. Zlín), Kláštov - zjištovací výzkum hradiska, Výroční zpráva ÚAPP Brno 2006. Brno 2007, 31, 32.

Kohoutek/Pavlíčková 2008 - J. Kohoutek/P. Pavlíčková: Vysoké Pole (okr. Zlín). Přehled výzkumů 49, 2008, 456, 457. 
Košta/Lutovský 2014 - J. Košta /M. Lutovský: Raněstředověký knižecí hrob z Kolína. Fontes Archaeologici Pragenses 41. Praha 2014.

Kouřil 2014 -P. Kouřil: Archaeological evidence of Christianity in relics of material culture of the $9^{\text {th }}$ and $10^{\text {th }}$ centuries in Moravia with focus on crosses. In: P. Kouril et al.: The Cyril and Methodius Mission and Europe - 1150 Years Since the Arrival of the Thessaloniki Brothers in Great Moravia. Brno 2014, 102-113.

Kouřil 2020 - P. Kouřil: Ostentatious Spurs from Mikulčice. In: L. Poláček et al.: Great Moravian Elites from Mikulčice. Brno 2020, 255-267.

Kouřil/Tymonová 2013 - P. Kouřil/M. Tymonová: Slovanský kostrový mohylník ve Stěbořicích. Spisy Archeologického ústavu AV ČR Brno 34. Brno 2013.

Langová 2010 - J. Langová: Vysoké Pole (okr. Zlín). Přehled výzkumů 51, 2010, 484.

Lennartsson 1997-1998 - M. Lennartsson: Karolingische Metallarbeiten mit Pflanzenornamentik. Offa 54-55, 1997-1998, 431-619.

Maixner 2005 - B. Maixner: Die gegossenen kleeblattförmigen Fibeln der Wikingerzeit aus Skandinavien. Universitätsforschungen zur prähistorischen Archäologie. Band 116. Bonn 2005.

Müllerová 2020 - M. Müllerová: New Synthesis of Early Medieval Iron Hoards from Slovakia. Archaeologia Austriaca 104, 2020, 283-301.

DOI: https://doi.org/10.1553/archaeologia104s283

Pieta/Ruttkay 2007 - K. Pieta/A. Ruttkay: Bojná. Mocenské a christianizačné centrum Nitrianskeho kniežatstva. In: K. Pieta/A. Ruttkay/M. Ruttkay (eds.): Bojná. Hospodárske a politické centrum Nitrianskeho kniežatstva. Archaeologica Slovaca Monographiae. Studia 9. Nitra 2007, 21-70.

Plaček 2001 - M. Plaček: Ilustrovaná encyklopedie moravských hradi̊, hrádků a tvrzí. Praha 2001.

Profantová 2011 - N. Profantová: Karolinské importy a jejich napodobování v Čechách, případně na Moravě (konec 8.-10. století). In: V. Turčan (zost.): Karolínska kultúra a Slovensko. Śtúdie. Zborník SNM. Archeológia. Supplementum 4. Bratislava 2011, 71-104.

Profantová 2014 - N. Profantová: Raně středověký depot č. 11 z vrchu Kláštov, kat. Vysoké Pole, okr. Zlín. Pravěk. Nová řada 22, 2014, 327-343.

Manuscript accepted 22. 6. 2021

Translated by Milan Rydvan

doc. PhDr. Pavel Kouřil, CSc.

Archeologický ústav AV ČR Brno

Čechyňská 19

CZ - 60200 Brno

kouril@arub.cz
Profantová/Profant 2004-N. Profantová/M. Profant: Encyklopedie slovanských bohů a mýtů. Praha 2004.

Robak 2013 - Z. Robak: Studia nad okuciami rzemieni w typie karolińskim VIII-X wiek. I. część. Archaeologica Slovaca Monographiae. Studia 18. Nitra 2013.

Robak 2014 - Z. Robak: Studia nad okuciami rzemieni w typie karolińskim VIII-X wiek. II. część. Archaeologica Slovaca Monographiae. Studia 19. Nitra 2014.

Robak 2018a - Z. Robak: The Sword and Sword-Belt in Carolingian times. The Warrior Burial 23 from Závada Reconsidered. Študijné zvesti Aú SAV 64, 2018, 149-177.

Robak 2018b - Z. Robak: Chronology and periodisation of imports of Carolingian military equipment in the Carpathian Basin between the eight and tenth centuries. Antaeus 35-36, 2018, 327-344.

Szczepanik 2020 - P. Szczepanik: Rzeczywistość mityczna Stowian pótnocno-zachodnich i jej materialne wyobrażenia. Toruń 2020.

Téra 2017 - M. Téra: Perun bůh hromovládce. Sonda do slovanského archaického náboženství. Červený Kostelec 2017.

Ungerman 2011 - Š. Ungerman: Schwertgurte des 9. bis 10. Jahrhunderts in West- und Mitteleuropa. In: J. Macháček/Š. Ungerman (Hrsg.): Frühgeschichtliche Zentralorte in Mitteleuropa. Studien zur Archäologie Europas 14. Bonn 2011, 575-608.

Ungerman 2017 -Š. Ungerman: Mečové pásy z 9.-10. století v západní a stř̌ední Evropě (typologie, chronologie, provenience a symbolika). In: K. Pieta/Z. Robak (eds.): Bojná 2. Nové výsledky výskumov včasnostredovekých hradísk. Archaeologica Slovaca Monographiae. Fontes 22. Nitra 2017, 253-280.

Váňa 1990 - Z. Váňa: Svět slovanských bohů a démonů. Praha 1990.

Wamers 2008 - E. Wamers: Glaubensboten. „Aristokratische" Kunststile des 8. bis 10. Jahrhunderts n. Chr. In: G. Eggenstein/N. Börste/H. Zöller/E. Zahn-Biemüller (Hrsg.): Eine Welt in Bewegung. Unterwegs zu Zentren des frühen Mittelalters. München - Berlin 2008, 37-50.

Wamers/Brandt 2005 - E. Wamers/M. Brandt (Hrsg.): Die Macht des Silbers. Karolingische Schätze im Norden. Regensburg 2005. 
